\title{
Chapter 5. Raising the House Post and Feeding the Husband-Givers: The spatial categories of social reproduction among the Minangkabau
}

\section{Cecilia Ng}

\section{Introduction}

\section{The Minangkabau}

The Minangkabau are among the largest of the ethnic groups in Indonesia. Besides being known for their matrilineal organization, the Minangkabau are also noted as energetic Muslim traders who have migrated far beyond their homeland in the province of West Sumatra. ${ }^{1}$ According to the 1980 census, the population of West Sumatra was approximately 3.4 million, of whom an estimated 3 million were Minangkabau. The majority of the Minangkabau population lives in the fertile upland plains where irrigated rice cultivation is their mainstay.

\section{Minangkabau Social Organization}

In this paper I am concerned with the principles of domestic spatial organization in Minangkabau society. The use of space in everyday and ceremonial contexts reveals perceptible patterns relating to the nature of Minangkabau social organization and shows the key definitions of male and female identity. Before proceeding to the discussion on the use of space, I deal briefly with four salient aspects of Minangkabau social organization, which are necessary to understand their divisions of space. ${ }^{2}$ I should perhaps remark that my interpretation of Minangkabau social organization differs to some extent from that of other scholars.

First, the population of a Minangkabau village is divided into a number of matrilineal clans (suku), which are further segmented into lineages (sa-payuang). The lineages are represented by panghulu (lineage headmen) and have been characterized by scholars as corporate groups. Most scholars researching Minangkabau society have tended to focus their attention on Minangkabau jural structures. There are, however, other informal patterns of social relations which are significant in the everyday lives of the villagers. One important category of social relations which cannot be viewed as a jural structure is the sa-kampuang. The sa-kampuang refers to the members with the same suku name (but who are not necessarily from the same clan) and who live in the same neighbourhood. 
Although the sa-kampuang has kinship and territorial connotations, it is not represented by a panghulu and is not a jural structure. The sa-kampuang is an informal and flexible category whose members come together most visibly on ceremonial occasions. In everyday life the relationships which are defined as sa-kampuang are of primary importance, especially to women who, in contrast to men, spend a large proportion of their time in the neighbourhood. Thus, I stress that it is essential to look at the informal though no less significant structures, if we are to understand Minangkabau social order.

My second point is that the emphasis placed on jural structures in the village gives unwarranted significance to the authority of men as mothers' brothers/panghulu. In my view, the Minangkabau are not only matrilineal but are also a matrifocal society. It is frequently reported by scholars on Minangkabau society that the mothers' brothers/panghulu are the key authority figures, representing their lineages in transactions with other lineages. This emphasis has led to the following statements:

the structurally most important relationship in the Minangkabau matrilineal system is one between mamak and kemenakan.

The mamak is the guardian of the kemenakan and is responsible for the well-being of the kemenakan, who are to continue their lineage ... The essence of Minangkabau matriliny is above all concentrated in the two generation relation of mamak and kemenakan (Kato 1977:57-58; emphasis added).

In contrast to men's command in the public domain, women are generally seen as having authority only within the minimal family unit and the matrilineally extended family, that is, within the domestic domain. This dichotomy of women:domestic::men:public is, in light of my findings, inaccurate and misleading. In Nagari Koto nan Gadang, women are vital actors: they negotiate and mediate interlineage relationships and act as representatives of their lineages in the fields of affinal relations and ritual obligations. To understand Minangkabau social organization it is necessary to begin from the perspective of the women, since kin relationships are conceptualized as categories which are based on the difference between groups of women.

Third, affinal categories constitute one of the most significant ways of ordering social relationships in Minangkabau society. These categories I gloss as husband-givers and husband-takers: this usage necessarily implies that men, and not women, are exchanged. One of the reasons for this unorthodox interpretation is that in the wedding ceremony the groom (who is 'rented' or 'bought') is 'handed-over' to the bride's lineage.

A final point concerns the Minangkabau residence pattern. Domestic residence for a boy changes as he grows up. Young boys before they are circumcised 
(usually at the age of eight to ten), sleep in their mothers' household. After circumcision, boys sleep in the mosque till they marry. There they receive adat 3 and Islamic instruction from the senior men of the village. If boys who have reached puberty were to sleep in the same house as their married sisters, it would, according to villagers, create an embarrassing situation for the married couple. Post-marital residence is uxorilocal and even when a new house is built for a married couple the land on which the house is built belongs to the wife's lineage. One of the most important ramifications of this residence rule is that women are spatially grouped together and in day-to-day life women form the core group within the village. This is especially so, too, because Minangkabau men tend to migrate (merantau) 4 to urban centres to find a livelihood.

\section{Spatial Organization in the House}

There are two types of houses in the village, the traditional Minangkabau house, rumah gadang (big house), and the modern house, rumah gedung (brick house). Few traditional houses are built these days, as the cost is far greater than that of modern houses. In Balai Cacang, ${ }^{5}$ ninetyseven of 135 houses are modern and thirty-eight traditional (see also Table 1). The modern house, which is modelled on the traditional house plan, is usually built within the compound of the lineage's traditional house. Assuming that relations between the households are good, the traditional house is usually used as the venue for any large ceremony sponsored by the household living in the modern house. Investitures of panghulu can only be held in the largest type of traditional house, that with thirty posts, and sponsors of the ceremony may 'borrow' (maminjam) a house from another villager for the purpose.

Both the modern and traditional houses are based on a rectangular plan. The traditional house is made of wood and the roof may be thatch (from the fibre of the enau palm) or, more frequently, of corrugated iron. In Nagari Koto nan Gadang there are three sizes of traditional houses (see Figure 1). The largest is the thirty-post house, and the two smaller ones are the twenty-post and the twelve-post houses. House plans are the same for all three sizes and the traditional house is built raised 1-2 metres off the ground.

At the left end of the house is an annex (anjuang) which is slightly elevated from the floor level of the house (see Figure 2). The annex is also qualified as the anjuang nan tinggi (the high annex), a reference to both its elevation from the floor level and to its symbolic significance as the pinnacle of the house. Sleeping quarters (biliak) are adjacent and are in the rear of the twenty-post and thirty-post houses. Curtained doorways of the biliak open out onto the hall (ruang). In the thirty-post house, the hall is divided into three zones: the ruang ateh (elevated hall) which is immediately in front of the sleeping quarters; the ruang tongah (central hall); and the ruang topi (side hall) by the windows at the 
front of the house. There are only two zones in the halls of the twenty-post house, the ruang tongah and the ruang topi. In the twelve-post house, there are no biliak and the hall is not differentiated into zones. The inner recess of the hall is, however, used as sleeping quarters if necessary.

Table 1. Composition of households

\begin{tabular}{|c|c|c|c|c|c|c|}
\hline category & description of composition & house & no. & $\%$ & \multicolumn{2}{|c|}{ category total \% } \\
\hline Single & $\begin{array}{l}\text { Single women who are divorced or whose } \\
\text { husbands are deceased }\end{array}$ & $\begin{array}{l}\text { modern* } \\
\text { traditional }\end{array}$ & 8 & $\begin{array}{l}5.9 \\
-\end{array}$ & 8 & 6 \\
\hline Eementary & $\begin{array}{l}\text { Woman + children } \\
\text { Woman }+ \text { husband }+ \text { children } \\
\text { Man + children }\end{array}$ & $\begin{array}{l}\text { modern } \\
\text { traditional } \\
\text { modern } \\
\text { traditional } \\
\text { modern } \\
\text { traditional }\end{array}$ & $\begin{array}{l}6 \\
3 \\
35 \\
9 \\
1 \\
-\end{array}$ & $\begin{array}{l}4.4 \\
2.2 \\
25.9 \\
6.7 \\
0.7 \\
-\end{array}$ & 54 & 40 \\
\hline Compound & $\begin{array}{l}\text { Woman }+\mathrm{Z}+\text { /or MZD + (B +/or MZS) }++ \\
\text { (spouse +/or ZH/MZ) + children } \\
\text { Man + (W) + children } \\
\text { Woman + (H) + (M + /or F) + her children + /or } \\
\begin{array}{l}\text { ZD/ZS + children's H + /or ZDH + children's } \\
\text { children + /or ZD's children }\end{array}\end{array}$ & \begin{tabular}{|l} 
modern \\
traditional \\
modern \\
traditional \\
modern \\
\\
traditional
\end{tabular} & $\begin{array}{l}6 \\
4 \\
- \\
- \\
15 \\
10\end{array}$ & \begin{tabular}{|l|}
4.4 \\
3.0 \\
- \\
- \\
11.1 \\
7.4
\end{tabular} & & \\
\hline & $\begin{array}{l}\text { Woman + SS } \\
\text { Woman + (H) + children + MMB } \\
\begin{array}{l}\text { Woman }+(H)+D+(D H)+Z D+(Z D H)+Z \\
+(Z H)+S\end{array} \\
\begin{array}{l}\text { Woman }+S+(S W)+S^{\prime} \text { s children + DS + } \\
\text { DSW + DS's children }\end{array} \\
\text { Woman + D + DH + D's children } \\
\text { Woman + H + D + S + HZD }\end{array}$ & \begin{tabular}{|l} 
modern \\
traditional \\
modern \\
traditional \\
modern \\
traditional \\
modern \\
traditional \\
modern \\
traditional \\
modern \\
traditional
\end{tabular} & \begin{tabular}{|l} 
\\
1 \\
1 \\
- \\
22 \\
11 \\
1 \\
- \\
-
\end{tabular} & $\begin{array}{l}- \\
0.7 \\
0.7 \\
- \\
16.3 \\
8.1 \\
0.7 \\
- \\
0.7 \\
- \\
0.7 \\
-\end{array}$ & 73 & 54 \\
\hline TOTAL & & & & & 135 & 100 \\
\hline
\end{tabular}

${ }^{*}$ Modern houses are brick and concrete buildings.

$\dagger$ Brackets show that these relatives are not part of all households within the described type. 
A THIRTY POST HOUSE

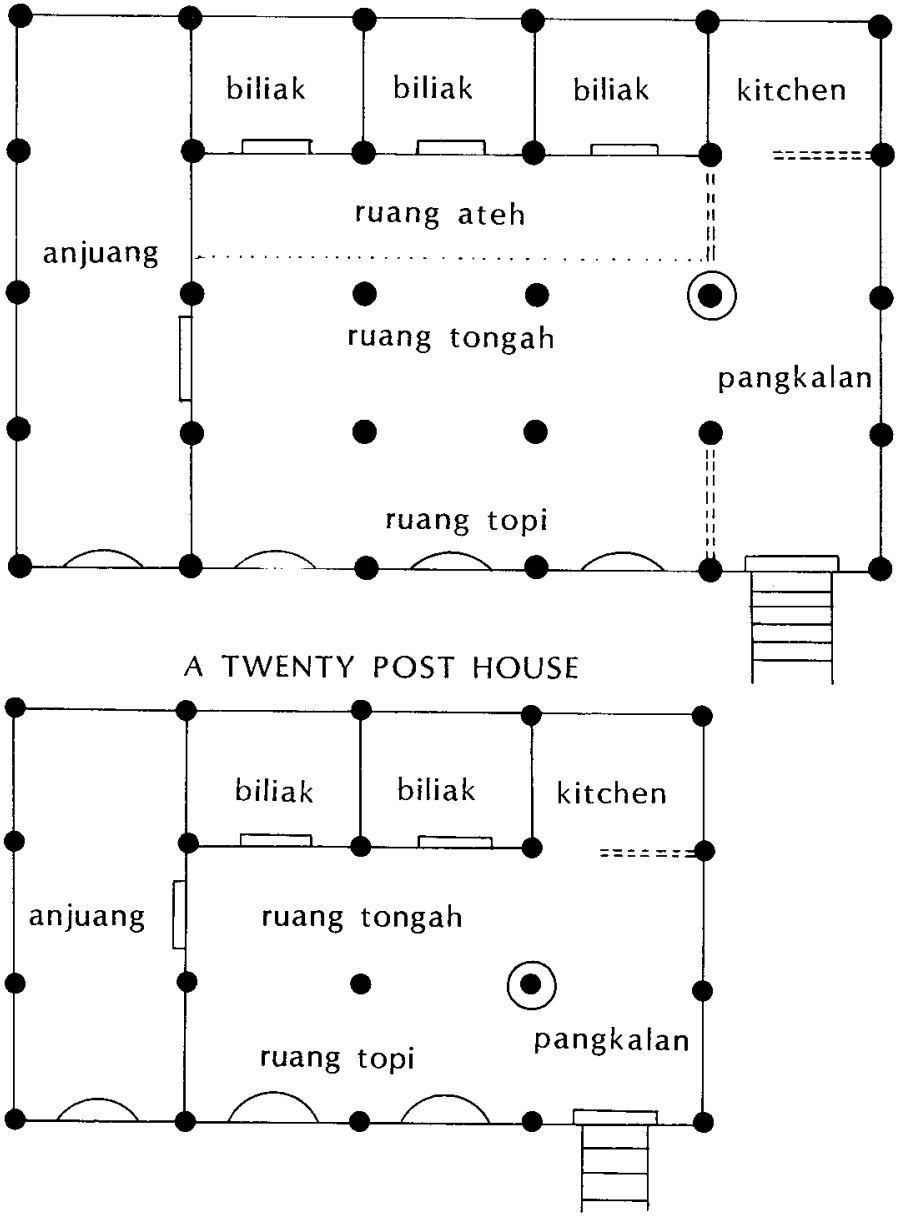

A TWELVE POST HOUSE
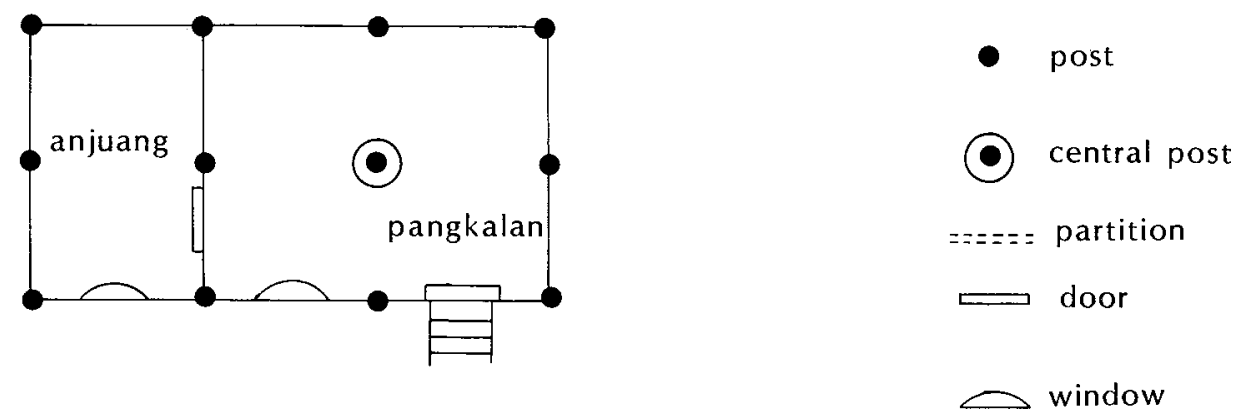

Figure 1. The rumah gadang

At the right rear end of the house is the kitchen (dapur), which is lower than the floor level of the hall. In some houses, the kitchen is built on ground level 
and a flight of steps leads down to the kitchen from inside the house. At the right end, in the front of the house, a flight of steps of uneven numbers (usually three, five or seven) leads up to the main door of the house which opens into the pangkalan (from pangkal: 'base', 'foundation', 'beginning', 'origin'). This space is usually on a lower level than the hall. The windows (two in a twelve-post house, three in a twenty-post house and four in a thirty-post one) are on the front of the house and face the courtyard (halaman).

Under the house (rumah dalam, inside house), wooden slats or filigree wooden walls enclose the space. Here the looms are set up, the weaver sitting directly below the annex. Chicken coops, firewood and coconuts are kept in the rear of the rumah dalam below the kitchen area. If there is more than one household living in the traditional house, another hearth may be built directly below the pangkalan or the kitchen.

In everyday life, the house is very much the domain of women and houses are said to be built for them. No self-respecting man would spend too much time during the day either in his wife's or his mother's house. In the daytime, men work in their offices, shops, the market, the fields and wet-rice lands or spend their time in the coffee house (warung), a place where men congregate to exchange gossip and news. They return to their wives' houses only after sundown for their evening meal and to sleep.

Women, in contrast, spend much of their time in or around the house, weaving in the rumah dalam, drying yarn, padi or rice cakes in the courtyard, pounding rice in the mortar in the courtyard, drawing water, preparing food in the kitchen and spinning or sewing in the pangkalan, visible to all the passers-by. A woman should be diligent and be seen or be heard (as in the case of the rhythmic beating of the weaving comb) to be diligent. One is a socially acceptable being only if one's actions are open to public witness. Windows and doors are thrown open in the early morning and are only shut when there is no one in the house and at night. Visitors announce their presence by shouting out from the courtyard and often women in the house can be seen standing by their windows, having conversations with passers-by in the courtyard. 


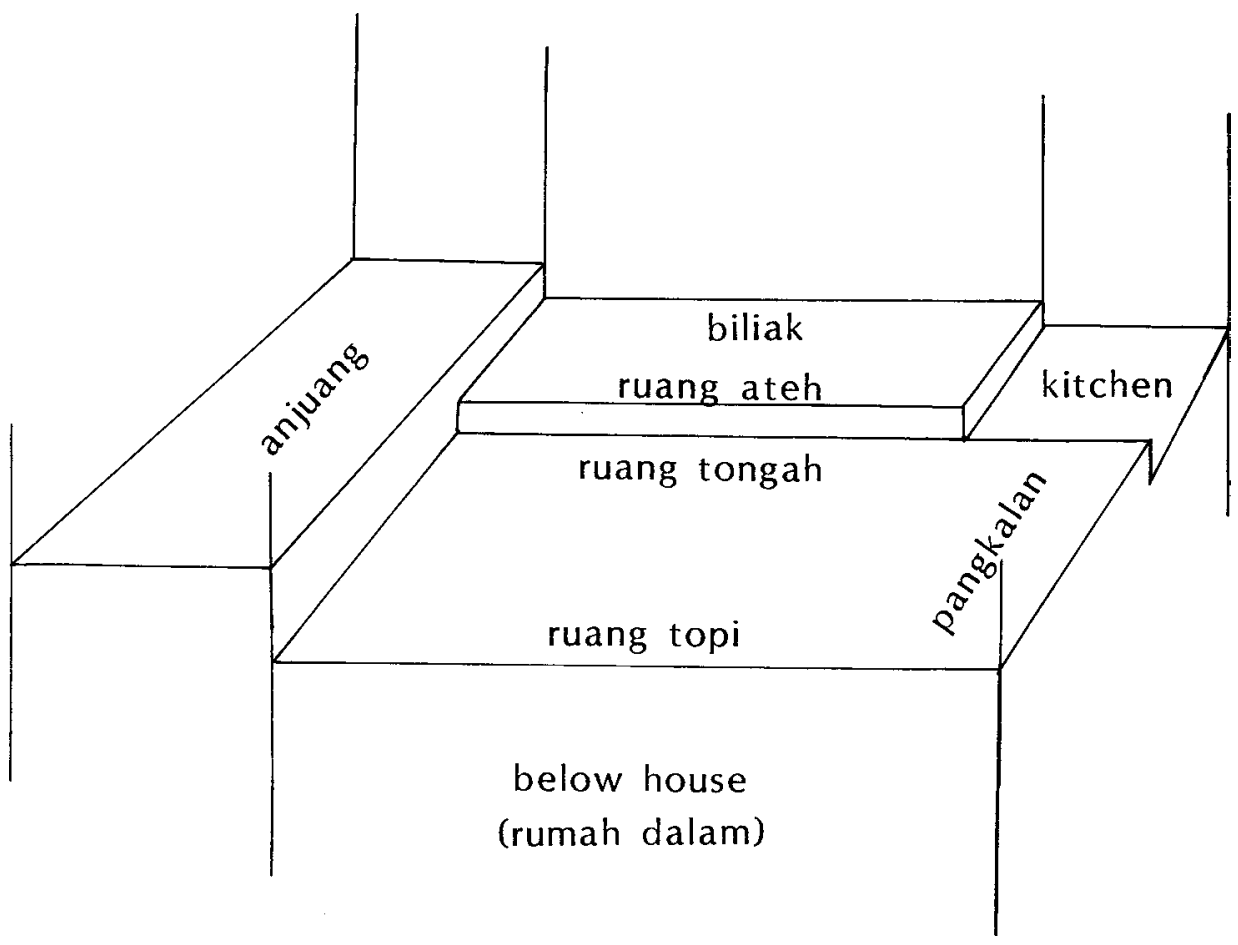

Figure 2. Levels in the rumah gadang

Within the house, the hall is a semi-private space. It is converted into a public space by laying mats on the floor. Guests sit on the ruang topi by the windows while the household members sit facing the guests on the ruang tongah. Most ritual activities are held in the hall and in the courtyard. In a few houses there may be chairs in the hall, but usually there is no furniture, except for a cupboard placed in the ruang tongah next to the annex. The valuables of the household, ceremonial cloths, heirloom bowls and jars, are kept locked in this cupboard and the eldest woman of the house holds the key. Daily meals are also eaten on the ruang tongah in privacy. Should a visitor call at such an inopportune moment, the meal is cleared away quickly, or if there is insufficient time, the visitor is invited to join in the meal, but the invitation is not meant to be taken seriously. The embarrassment is felt by both the household members and by the visitor for having intruded.

At night, the windows and doors are shut and the house becomes a private space. Generally villagers do not visit each other after nightfall, except on invitation or when there is a ceremony held in the house. This is especially so when there is a recently married couple sleeping in the house.

Sleeping arrangements in the traditional house follow a specific order (see Figure 3). The most recently married girl and her husband sleep in the anjuang 
(annex). ${ }^{6}$ This room is regarded as hers and is kept vacant for her, even if she and her husband are on a protracted merantau. On the marriage of a younger girl (either sister or mother's sister's daughter) in the house, she vacates the annex and moves to the bedroom adjacent to the annex. The occupants of the biliak move one room down towards the kitchen. Since marriage follows birth order, ideally and generally in practice, the oldest woman sleeps in the biliak next to the kitchen. However, if there were insufficient biliak, she would sleep in the pangkalan. When there is a spare biliak, the one adjacent to the annex is kept vacant to ensure the newly married couple has more privacy. Unmarried girls share the biliak of their mother if her husband no longer visits her. Alternatively, the unmarried girls sleep on the ruang ateh or the ruang tongah near the central post (tonggak tuo) of the house.
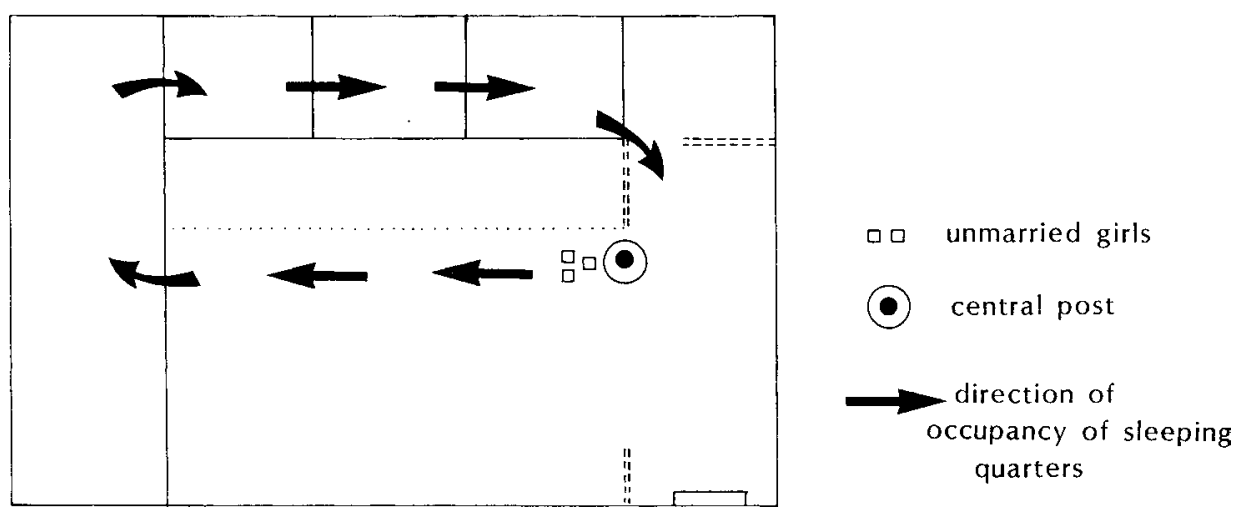

Figure 3. Sleeping order in the traditional house

Beds are the main furniture in the biliak and the annex. A sofa and a dressing table are also standard furniture in the annex. The annex and the biliak are private spaces and personal possessions, for example, clothes, are kept in the biliak. Except on ceremonial occasions and on the invitation of the occupant, female guests do not enter the annex or the biliak. The only men who may enter these rooms are the husbands and the unmarried sons of the occupants.

The kitchen is also a private space. Unless one is a close matrilineal relative or a friend, to enter the kitchen during non-ceremonial occasions, or without invitation, is considered as prying since what one consumes as part of daily fare is simple and as a subject of discussion is considered embarrassing (malu). During ceremonies, women of the sponsor's sa-kampuang may enter the kitchen to assist but guests may not. When ostentatious cooking is done, as for the large ceremonial feasts, a simple shack is erected to serve as the cooking space in the compound, partly because more space is needed and partly to be in public view.

In front of the kitchen is the pangkalan. This is a public space which everyone entering the house must necessarily pass through. Guests may sometimes sit in 
the pangkalan instead of the hall. Here, too, older women at the end of their reproductive cycle sleep.

In the traditional house, there are levels of connected meanings. First, there is a division of space where procreativity takes place, and the space for social interactions. The spaces where procreativity (the annex and the biliak) takes place are private, while the space where social discourse and interactions are conducted (the ruang) is public. There is a gradation of public to private space in the ruang itself (see Figure 4); the ruang topi is a semi-public space where the guests sit, and more public than the ruang tongah on which the household members sit facing and entertaining their guests. As we proceed to the rear of the house, open space becomes enclosed as the biliak, and these rooms are private.
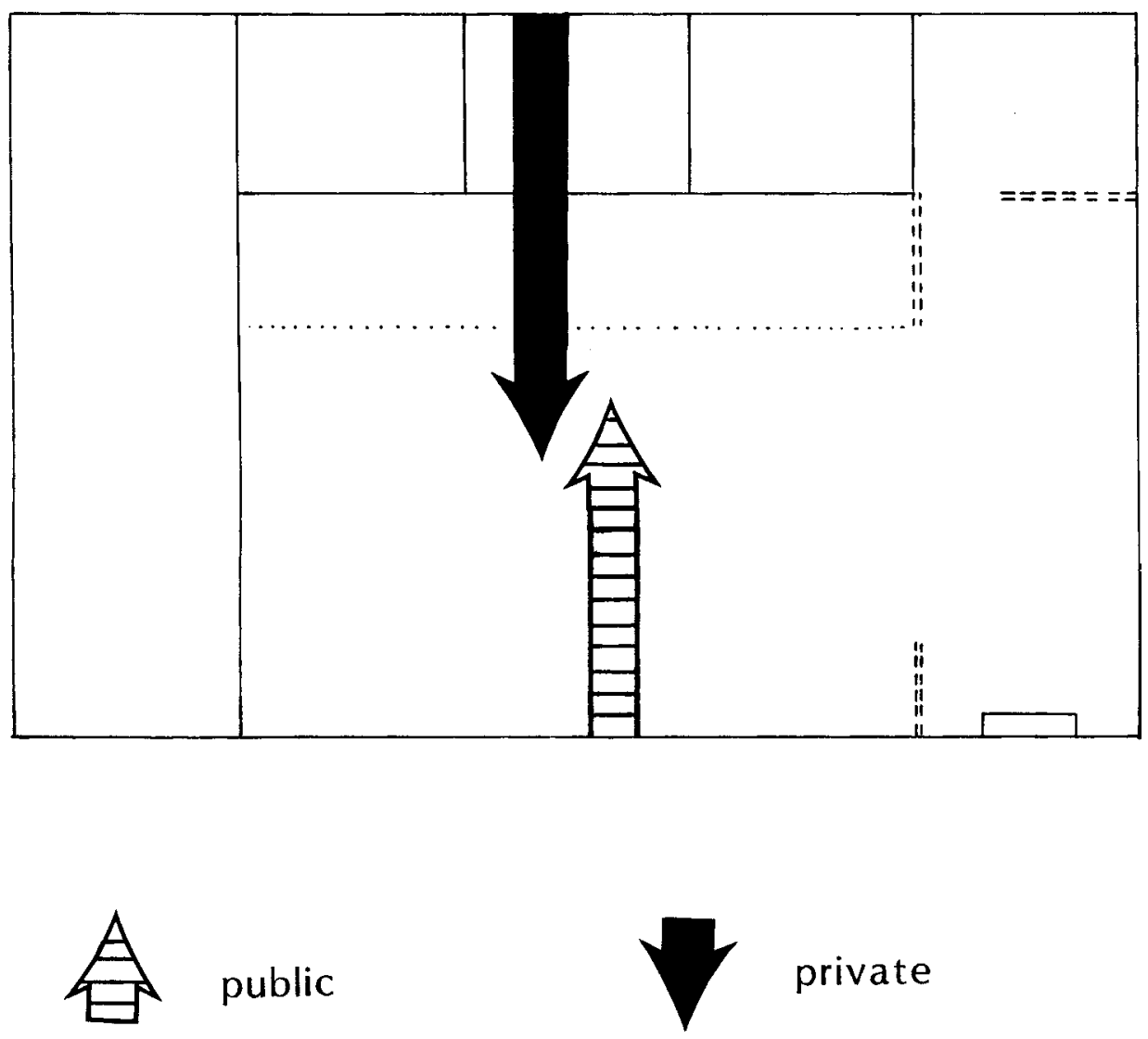

Figure 4. Public and private space

The annex is a private space where a young girl begins her reproductive cycle and here, a groom's agency is transformed into children for the continuity of the lineage. In opposition to the annex, the kitchen area (that is, the kitchen and the pangkalan) is where women at the end of their reproductive cycle sleep. 
Here too the corpse is bathed before she/he is laid in state in the middle of the ruang topi and ruang tongah.

The kitchen is where a transformation of another kind, raw food into cooked food, takes place. Food is the means for enhancing and affirming social relationships (see Figure 5). The kitchen is in the rear of the house and connects, in a circular route, the areas of biological reproduction and the public areas (the ruang and the pangkalan) where social interactions take place and where new elements from the external community, men, are introduced to perpetuate the lineage.

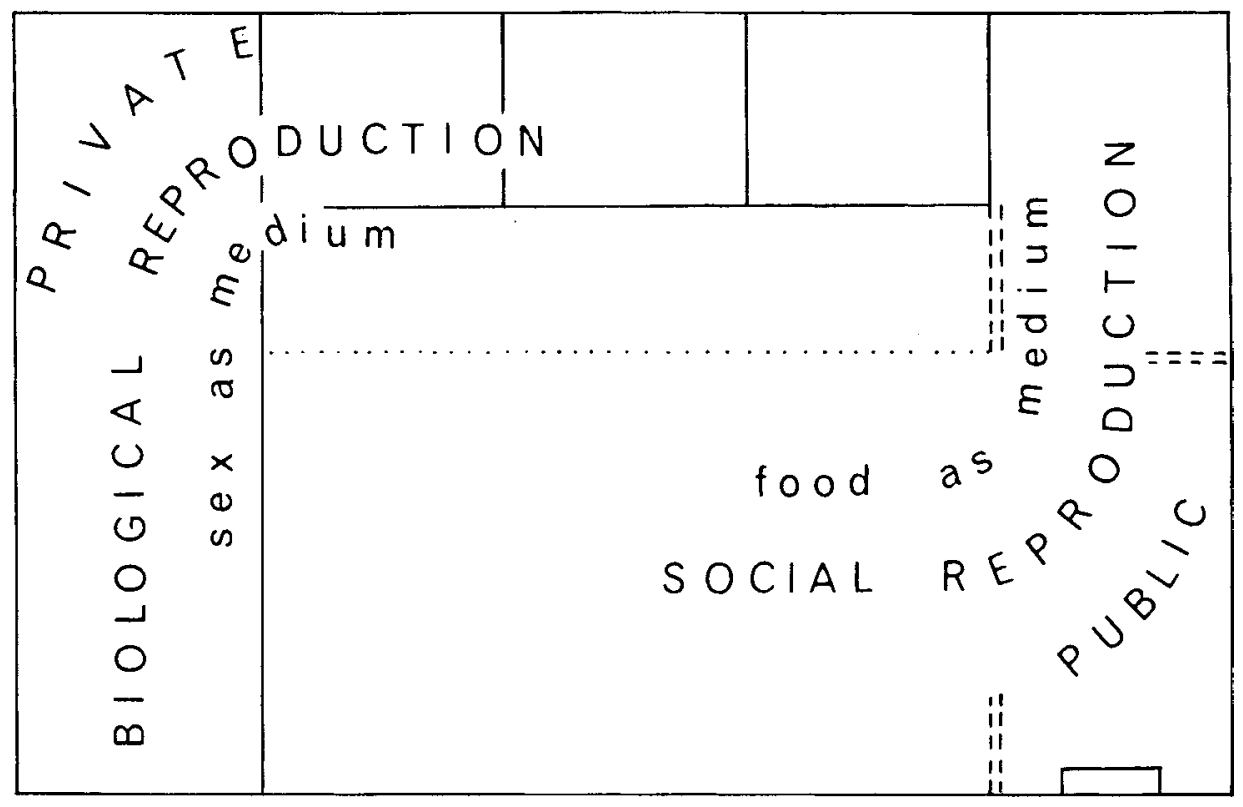

Figure 5. Meanings in the traditional house

We then have a set of oppositions in the meanings underlying the use of space which can be presented as shown in Figure 6. 


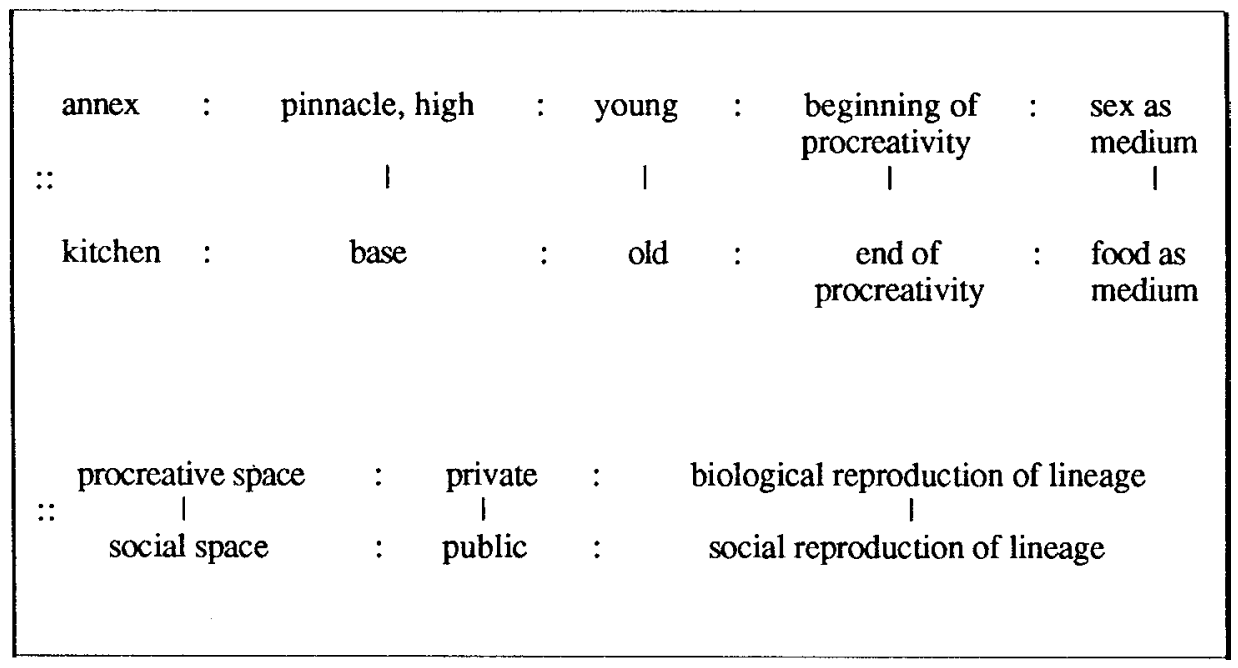

Figure 6. Underlying meanings in the use of space

Implicit in the use of space is the dimension of time; that is, the life cycle of the woman (see Figure 7). When unmarried, a woman sleeps near the central post. She proceeds to the annex as she enters her reproductive phase and then moves down the biliak towards the kitchen. At the end of her period of procreativity, she moves into the pangkalan. The young girls sleeping near the central post can be interpreted as symbolic of the fact that they are the progeny through whom the lineage will continue. This is indicated in the house-building ceremony (mandirikan rumah, literally 'raising the house') where, as the climax of the occasion, unmarried girls of the lineage, for whom the house is said to be built, symbolically pull the central post (tonggak tuo) erect. The sexual symbolism is blatant enough, but another meaning is that the young girls form the continuity of the lineage. Further evidence that the central post of the house is closely associated with the continuity of the lineage is the practice of burying the placenta and the umbilical cord of a newborn member of the lineage at the foot of the post.

\section{Use of Space in Ceremonies}

So far I have discussed Minangkabau organization of domestic space. In this section I turn to the use of space on adat ceremonial occasions. Before proceeding to describe the general principles in the use of space on ceremonial occasions and presenting an account of a specific ceremony, a part of a wedding, it is necessary here to state briefly the sociology of adat ceremonies. 


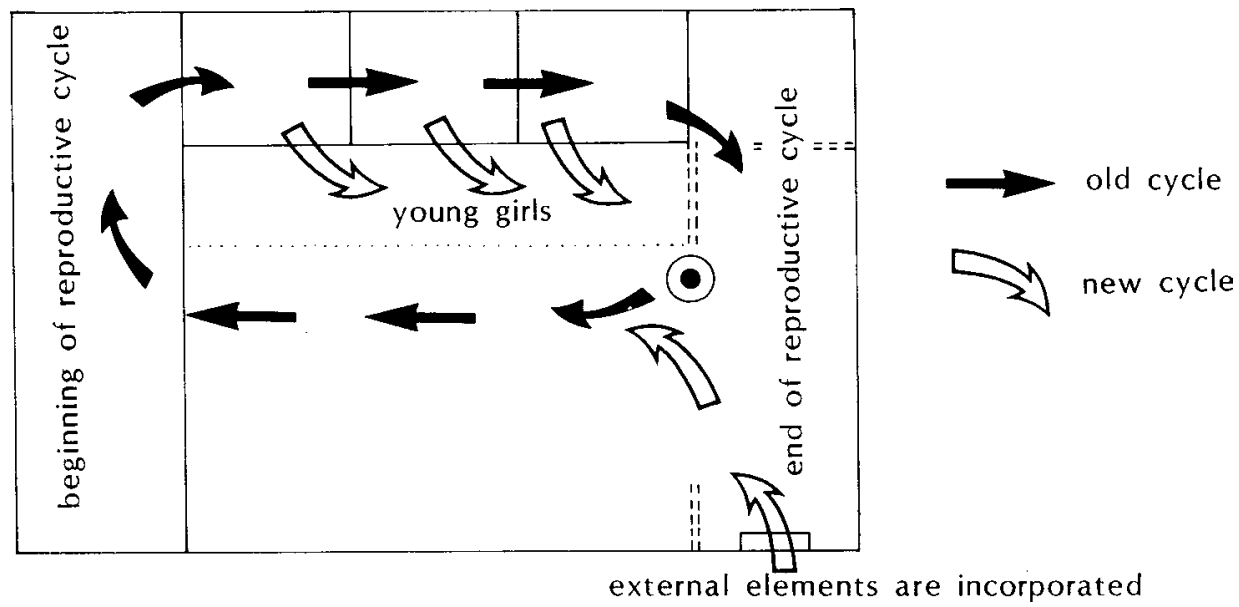

Figure 7. Life cycle in the traditional house

\section{Sociology of Adat Ceremonies}

Women are the principal figures in adat ceremonies either as organizers or as participants. While women are present in all adat ceremonies, including those in which men play central roles, men do not attend those ceremonies where they do not have central roles to perform. This is partly because adat ceremonies are always held in the sponsor's house and since the house is mainly women's domain, women's presence is indispensible. This differential participation of men and women reflects their positions in Minangkabau society. Women form the core groups of lineages and are mediators between affinal categories. Since adat ceremonies concern kin networks, women's presence is essential on these occasions. In contrast, men who are interstitial to Minangkabau social organization, are not required to participate in all adat ceremonies.

In most adat ceremonies, the female participants can be divided into the following categories (see Figure 8):

1. Women of the sponsoring lineage and women from the sponsoring lineage's sa-kampuang.

2. Women of the sponsor's husband-giving lineages and the women of the husband-givers' sa-kampuang.

3. Women of the sponsors' husband-taking lineages and the women of the husband-takers' sa-kampuang.

Men participate only in major adat ceremonies and in the following capacities:

1. Men of the sponsoring lineage and their sa-kampuang men.

2. In-married men (orang sumando) of the sponsoring lineage and men of the in-married men's sa-kampuang. 
3. Panghulu of the sponsoring lineage and the panghulu of the sa-kampuang of the sponsoring lineage.

4. Panghulu of the guest lineage and the guest lineage's sa-kampuang (the guest lineage would be either the bride's or the groom's in wedding ceremonies).

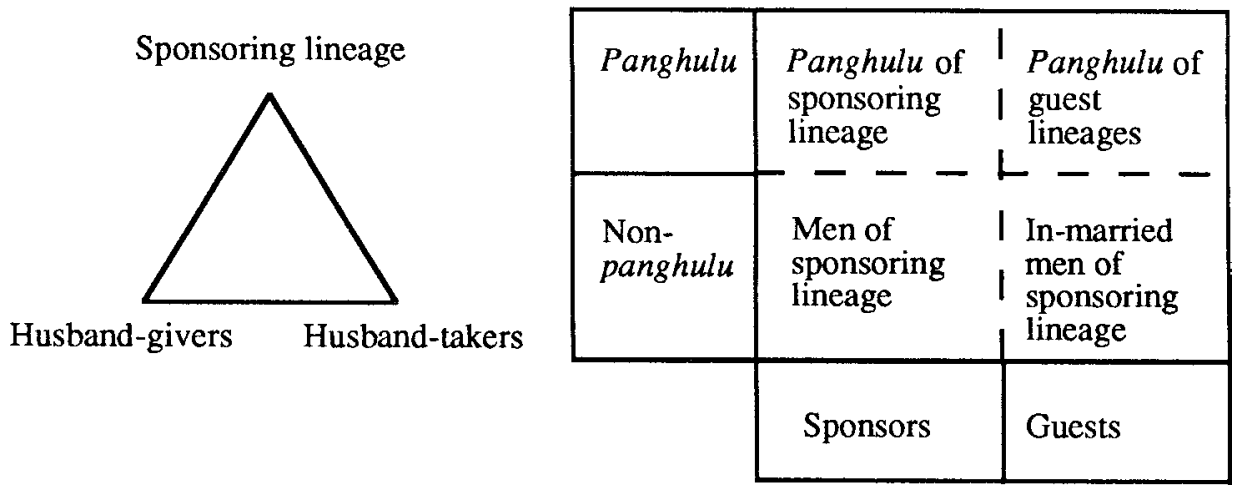

Figure 8. Participants in adat ceremonies

\section{General Patterns}

This section summarizes the pattern of spatial organization in ceremonial context. The interpretation is based on observation of a wide range of ceremonies (birth, death, weddings), which cannot be elaborated here.

The use of space in ceremonies follows a specific pattern (see Figure 9). Women of the sponsor's husband-giving lineages sit on the ruang tongah or in the section of the ruang ateh near the annex. The women of the sponsor's husband-taking lineages are allocated the ruang topi or the area of the ruang ateh nearer the kitchen. In my interpretation this pattern is significant. Husband-givers contribute to the reproduction of the sponsor's lineage and are seated in the areas closer to the space for procreation. In contrast, husband-takers, who do not contribute to the biological reproduction of the sponsor's lineage, are seated further away from the space of procreativity. 
Inside Austronesian Houses

When only women participate in the ceremony:

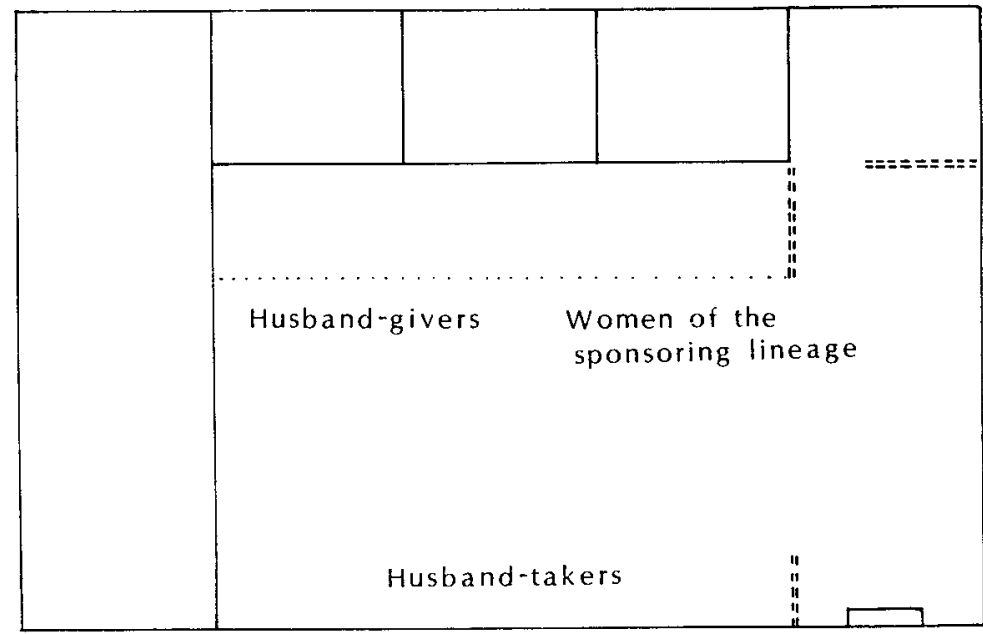

When men and women participate in the ceremony:

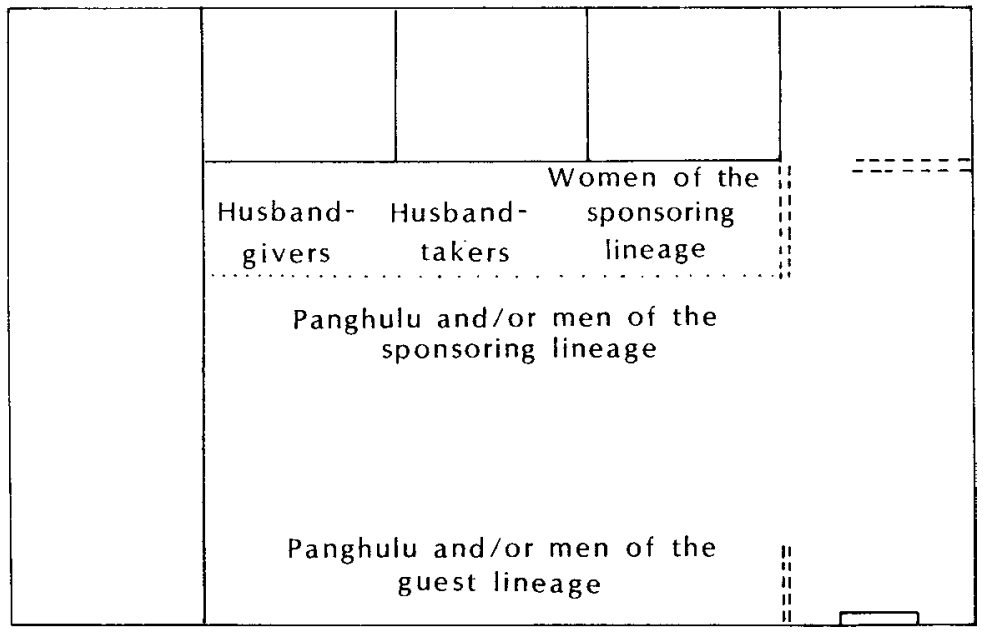

Figure 9. Spatial organization in adat ceremonies

For men, when there are only two groups of men present in the ceremony, those who are from the sponsor's lineage sit in the ruang tongah, while guests sit in the ruang topi, the more public space. When panghulu are involved in the ritual as well, those of the sponsor's lineage sit in the ruang tongah nearer the annex, while guest panghulu sit in the ruang topi. The men of the sponsor's 
lineage sit on the ruang tongah near the kitchen end, while the in-married men sit in the ruang topi near the door.

\section{A Wedding Ceremony}

The following are my fieldwork notes about a specific wedding ceremony, the malam basampek ('night of chance [of escape]'). ${ }^{7}$ This ceremony is held in the house of the bride who sits in full ceremonial costume throughout the ceremony. Acting as sponsors are the women and young men of the bride's lineage and sa-kampuang. The ceremony is held in the evening and marks the groom's first night in his wife's lineage house. The use of space in this ceremony is of especial interest, as it shows the incorporation of the groom into his wife's lineage.

\section{The Malam Basampek}

At Endy's (the groom's) house, the young boys of his lineage and sa-kampuang gather to await the arrival of two boys from Ery's (the bride's) lineage, who will present a betel-nut box to invite the groom to his bride's house on this night. Endy's mother and her sister pack a bundle of his personal possessions (shoes, clothes, sarong, cigarettes) amidst comments from the sa-kampuang women, who have begun to gather in the house, that his mother never need wash Endy's clothes again.

After the two boys from Ery's lineage arrive, at about nine in the evening, the women of Endy's lineage and sa-kampuang leave with the bundle of his possessions ostentatiously carried on a tray. Unmarried girls also accompany the women. The unmarried boys and Endy form the rear party.

At the bride's house the groom is met at the doorway by two elderly women from her lineage. Ery is seated on the nuptial seat in the ruang topi. The unmarried boys of her lineage are seated on the ruang tongah and plates of cakes and betel-nut are laid out on the mats. Endy and his boys sit in the ruang topi, while the women from the groom's party are shown to the ruang ateh and the annex.

Shortly after the guests' arrival, rhetorical exchange between speakers (men) representing the groom's and bride's sections begins. The speaker of the bride's side requests that the groom sit with the bride. The speaker of the groom's side demurs. After much procrastination, the speaker representing the groom's lineage finally agrees to the groom sitting with the bride. Two elderly women from Ery's sa-kampuang present a betel-nut box to the speaker of the groom's side as an invitation to the groom to sit with the bride. The women then lead the groom to his seat next to Ery. During this break in the oration, the boys have their refreshments and Endy returns to the ruang topi. A second round of rhetorical exchange soon begins with the speaker of the groom's lineage asking to take leave, but the bride's speaker tries to detain the groom's entourage. The groom's 
group finally manages to depart by one o'clock in the morning. However, there are cases when the oratory continues until three or four in the morning.

When the oratory is over, the boys from the groom's party leave and Endy tries to leave with them. The boys from the bride's side physically restrain him from leaving while the boys of the groom's party pull at him to leave with them. This is acted out playfully, but, as reported by my informants, there have been occasions when fights have broken out between the two parties. When the groom is led back to the house, the senior women of the bride's lineage serve him his meal in the ruang ateh. Endy spends the night in the annex with his bride.

\section{Interpretation}

The rite of passage of the newly married couple is marked by changes in the use of space. The annex, the room where a girl enters the realm of procreativity, now becomes Ery's personal space. From being a product of the lineage, sleeping near the central post, the symbol of continuity, she becomes a reproducer for her lineage, generating further continuity.

In the groom's case, his change of residence demonstrates that he becomes the agent through whom reproduction of Ery's lineage is made possible. His personal possessions are ceremonially carried to the bride's house by the women of his lineage and solemnly handed over to the women of Ery's lineage. On the first evening that the groom spends in his bride's house, he moves from the ruang topi, the most public social space in the house, to the ruang ateh where he is fed, a progression towards the private space of procreativity before finally retiring to the annex, the point of entry into the reproductive cycle.

\section{Food}

Food is exchanged among female affines in adat ceremonies as well as on non-ritual occasions. A generalized hierarchy of food appears in Table 2.

In everyday domestic life, the obtaining, preparation and serving of food are principally women's work. Men contribute towards the food expenses of their wives' households and some men also contribute to their mothers' or sisters' households. Often, however, a man's contribution is minimal, sufficient to meet only the cost of his own consumption needs. On the whole, women are mainly responsible for meeting the major portion of their households' daily food expenses, either from their earned income or by their efforts expended in collecting vegetables in the village or from the gardens, fishing in fresh-water ponds and in attending to wet-rice fields. Daughters from the age of twelve are taught to cook and take on responsibility for shopping, preparing and serving meals. Men do not assist in the preparation of food in the domestic sphere. But they usually cook the main meat dishes for ostentatious adat ceremonies and are often cooks in urban Minangkabau restaurants. 
Table 2. Hierarchy of food and labour

\begin{tabular}{|c|c|c|c|}
\hline CONTEXT & LABOUR & FOOD & COST \\
\hline $\begin{array}{l}\text { Ostentatious, highly public } \\
\text { occasions such as investitures and } \\
\text { large-scale weddings }\end{array}$ & $\begin{array}{l}\text { Sa-kampuang men } \\
\text { cook the main meat } \\
\text { dish or a cook (male or } \\
\text { female) is hired; } \\
\text { sa-kampuang women } \\
\text { prepare other dishes } \\
\text { and ingredients }\end{array}$ & $\begin{array}{l}\text { Buffalo meat or beef } \\
\text { cooked in a variety of } \\
\text { spices and in coconut } \\
\text { milk }\end{array}$ & Expensive \\
\hline $\begin{array}{l}\text { Modest weddings, birth and death } \\
\text { ceremonies }\end{array}$ & $\begin{array}{l}\text { Sa-kampuang women } \\
\text { prepare and cook the } \\
\text { meal or a cook is hired }\end{array}$ & $\begin{array}{l}\text { Goat meat, chicken and } \\
\text { large whole fish }\end{array}$ & \\
\hline Meal for sa-kampuang helpers & $\begin{array}{l}\text { Women and girls of the } \\
\text { sponsoring lineage } \\
\text { prepare and cook the } \\
\text { meal }\end{array}$ & $\begin{array}{l}\text { Vegetables such as } \\
\text { jack-fruit and taro } \\
\text { stems, small fish }\end{array}$ & \\
\hline Everyday, domestic situation & $\begin{array}{l}\text { Women and girls of the } \\
\text { household prepare and } \\
\text { cook the meal }\end{array}$ & $\begin{array}{l}\text { Leafy vegetables, } \\
\text { soybean, eggs; less } \\
\text { variety of spices and } \\
\text { usually no coconut milk } \\
\text { used }\end{array}$ & Cheaper \\
\hline
\end{tabular}

For feasts in birth and death ceremonies, fish and chicken are served. Wedding feasts must include at least some dishes of goat curry (gulai kambing). ${ }^{8}$ The more well-to-do villagers serve beef curry as the main dish in their wedding feasts. For investitures, water-buffalo meat is an essential part of the ceremonial feast. Vegetables, except in the form of potato cakes (perkedel), ${ }^{9}$ a non-indigenous dish, are not served in ceremonial meals, but may be included in the meat dishes. A ceremonial meal usually includes several other side-dishes, like noodles, fried chicken and whole fish. The latter two dishes are often placed on high plates for show, and are not meant to be eaten by guests.

The preparations of refreshments and food for adat ceremonies are labour-intensive and mainly women's tasks. Women of the sponsoring lineage and their sa-kampuang women are responsible for making various kinds of cakes, grating coconuts, preparing ingredients and cooking the dishes required for modest ceremonial meals. An expert female cook may be hired to cook the goat curry; if not, it is the work of the women of the sponsoring lineage and their sa-kampuang. In return for their assistance, the sa-kampuang women are served a midday meal by the sponsors. This meal usually comprises rice, a vegetable curry (jack-fruit curry or a taro stem curry) and small fried fish. Butchering of goats, cows and water-buffaloes is done by men of the sponsoring lineage and their sa-kampuang. These men (or a male cook who may be hired) cook the beef or water-buffalo meat curries for the high adat ceremonies. However, obtaining and preparing the ingredients (chopping onions, grating chillies, ginger, coconuts, etc.) still remain the work of women.

Men's labour is used at highly public and ostentatious ceremonies, while women's labour is employed in the less public, modest occasions and in preparing the ingredients and cooking the rice, potato cakes and noodles for the lavish 
meals. ${ }^{10}$ This pattern in the division of labour with regard to food also occurs in the organization of ceremonies; while women negotiate and implement decisions, men legitimate and validate these negotiations through their oratory.

\section{Exchange of Food}

While sex is the means by which a lineage is biologically reproduced, food is the medium for affirming the lineage's social relations, particularly affinal relations. In turn, good social relations make possible further biological reproduction of the lineage. Earlier, in the section on the use of space in traditional Minangkabau houses, I related food to sex. The annex is where virgins are transformed into reproducers of their lineage and where men's agency is transformed into children of their wives' lineages. In the kitchen raw food is transformed into cooked food, a medium for affirming social relations and, therefore, social reproduction. The connection of meanings is not so far-fetched. In Indonesian, makan (to eat) is a metaphor for sexual intercourse. That food and sex are connected is also demonstrated in the pattern of food exchange in ceremonial contexts. The items of food exchanged can be classified as: (1) cooked food (often served as a meal), (2) uncooked food (rice, meat, fish, etc.), and (3) cakes and fruit.

Cakes and fruit are a category of food apart from meat, fish, vegetables and rice. Unlike these latter items, cakes and fruit are not considered substantial foods and a meal is not defined by their presence. Cakes, a labour-intensive food, form a high proportion of exchanges between guests and sponsors. Sponsors always serve food, either in the form of a meal or as elaborate cakes, to their guests. On occasions when a meal is served, guests (both husband-takers and husband-givers) give hulled uncooked rice to help, according to my informants, the sponsors with the economic burden. Figure 10 shows details of exchanges between the affines on weddings. 


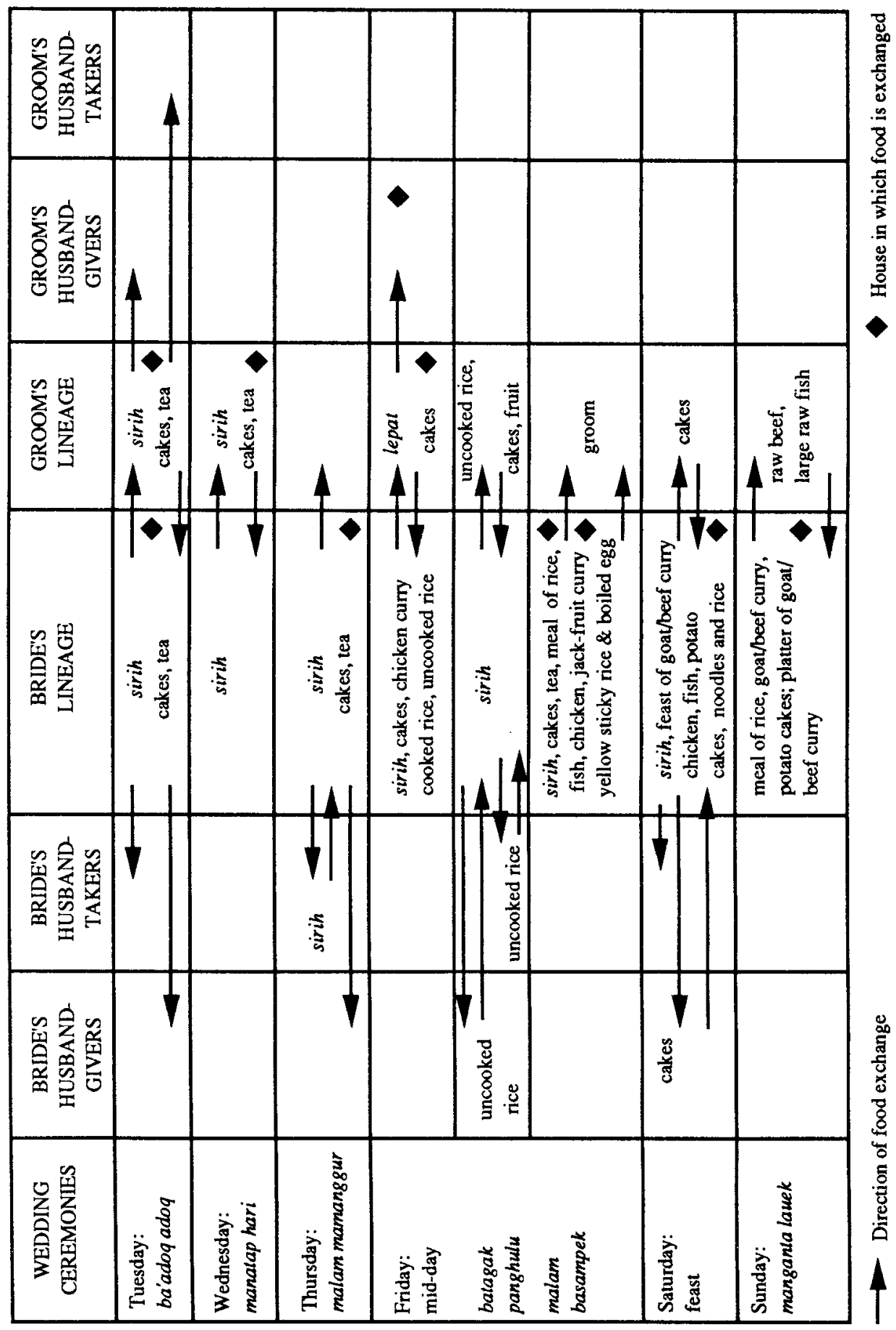

Figure 10. Exchange of food in the wedding ceremony 
Leaving out exchanges of cakes and fruit, a noticeable pattern in the exchange of substantial foods is that husband-takers tend to give cooked food to their husband-givers, and the items they receive from their husband-givers are raw food. This pattern of exchange is most explicit in the exchanges between the women of the groom's lineage and those of the bride's lineage. On the day of the main wedding ritual, the bride's lineage women present chicken curry, rice and cakes to the women of the groom's lineage. Further, on the Sunday after the main wedding ritual, the groom's lineage women give raw beef and raw fish to the mother of the bride. In return they receive, besides a meal, a platter of goat curry.

This pattern of exchange, where husband-givers give raw food and in return receive cooked food from their husband-takers, is also shown in the exchanges during the Fasting Month. A common scene during the Fasting Month is women carrying trays of cooked food (meat curries, fried fish, rice, cakes and fruit) to their mothers-in-law. The mothers-in-law give their daughters-in-law coconuts and cash. The pattern of food exchange, that is, husband-givers : raw :: husband-takers : cooked, is but a resonance of a more important one: the exchange of men. The husband-givers, the suppliers of men who are the agents for continuity in their husband-taking lineages, are the givers of raw food. Put in another way, the husband-giving lineages are the givers of raw materials which in their husband-taking lineages become transformed into further life-giving substances. The exchange of food is not only an act of reciprocity but the nature of items exchanged (raw or cooked) explicates the nature of relations between the affinal dyads, the husband-givers and the husband-takers.

\section{Conclusion}

Embodied in the spatial organization and the exchange of food are key definitions of male and female identity and of the principles of social order.

\section{Key Definitions}

Procreative status is the central source of women's identity. The transitions from one phase in the life cycle to the next (for example, unmarried to married, recently married to married with children, to old with grandchildren - this is evidently marked in ceremonial costumes) are objectified in the use of domestic space, particularly in the organization of sleeping space. As a young girl, a woman sleeps near the main pillar (at the base of which the placenta and umbilical cords of all offspring of the house are buried), then she moves to the annex at the beginning of her procreativity. During her procreative cycle she moves through a series of rooms till she reaches the kitchen area at the end of her procreative cycle.

Women are thus centrally identified with the continuity of their matrilineal group. The woman, the house and the continuity of the matrilineal group are 
all closely linked. The house is still an important symbol of lineage identity. Even in contemporary times when non-traditional houses are common, lineage members identify themselves with the traditional house where they come from. The house is thus primarily the women's domain, and houses are said to be built for women. Encapsulated in the use of domestic space is the model of lineage continuity. The passage of a woman's life is marked by a circular movement in the house. As she approaches the end of her reproductive life, her daughters would be beginning their cycle of reproductivity and movement around the house. From the womb, then, perpetual cycles of continuity issue. Women's orientation is inwards, fixed within the house and the lineage.

While women are defined as the source of continuity, men are essential to the cycle of continuity. They are the agents who are brought in from the outside or who are sent out to create children, the future reproducers of the women's lineages. The crucial principle in the exchange of food is that husband-givers give raw food, while husband-takers give cooked food, thus identifying the givers of men as the givers of raw material which is transformed into further life-giving substances.

Men's orientation is outwards. A man's life is marked by a series of outward movements: from the house to the mosque at puberty, from there to another neighbourhood (his wife's), and usually to another region outside the Minangkabau heartland to find a better living.

The crucial basis of social order is the circulation of men as agents of continuity for the lineages. This is best demonstrated in the exchange of food. In addition, the use of space during ceremonies also marks the basis on which groups of women are distinguished. In the use of space (and even more so in ceremonial costumes), women are explicitly classified in triadic categories, as women of their own matrilineal group, husband-givers and husband-takers. Husband-givers who contribute directly to the reproduction of the sponsor's lineage are seated near or in the procreative space, while husband-takers, who make no direct contribution to the reproduction of the sponsor's lineage, are allotted space further from the areas identified with procreative activities.

The transitions the Minangkabau make around the house, the allocation of specific space to specific social categories are then a template of the key definitions of male and female identity and underline the divisions in the society.

\section{References}

Dobbin, Christine

1983 Islamic revivalism in a changing peasant economy: Central Sumatra, 1784-1847 (Scandinavian Institute of Asian Studies Monograph Series No. 47). London and Malmo: Curzon Press. 


\section{Kato, Tsuyoshi}

1977 Social change in a centrifugal society: the Minangkabau of West Sumatra. Unpublished PhD thesis. Cornell University, Ithaca, N.Y.

1982 Matriliny and migration: evolving Minangkabau traditions in Indonesia. Ithaca: Cornell University Press.

Naim, Mochtar

1974 Merantau: Minangkabau voluntary migration. Unpublished PhD thesis. University of Singapore.

$\mathrm{Ng}$, Cecilia S.H.

1987 The weaving of prestige: village women's representations of the social categories of Minangkabau society. Unpublished PhD thesis. The Australian National University, Canberra.

\section{Notes}

Field research on which this paper is based was carried out between 1980 and 1981, in the village of Nagari Koto nan Gadang in the district of Lima Puluh Kota in West Sumatra.

${ }^{1}$ Islam was introduced in the late sixteenth century through trading connections with Muslim traders from the Middle East (Dobbin 1983:119).

2 The discussion on Minangkabau social organization is necessarily brief and simplified here. I have elsewhere discussed Minangkabau social organization at greater length (see $\mathrm{Ng}$ 1987).

3 Adat is a term which covers a variety of meanings, from legalistic rules, custom and tradition to the right and proper way of living. The term is often translated as customary law. Although adat as used in particular contexts can refer to explicit rules (about inheritance, descent group membership, dispute settlements), adat in its general sense refers to the Minangkabau heritage, that is those orientations which make for the specific identity of Minangkabau villagers.

4 Merantau (voluntary migration) is from the root word rantau (coastal/riverine areas), meaning to go to the rantau. Initially, merantau was undertaken in groups to extend the Minangkabau territory and for trade. However, merantau has become an institutionalized practice where individuals go beyond their natal villages or the Minangkabau heartland, usually to urban centres, to seek their livelihood. Merantau can also be regarded as a rite of passage to adulthood for young men. The commonly cited effects of merantau are the relief of pressure on subsistence lands in the highlands, and the low ratio of adult men in the villages of the heartland. Up till the nineteenth century, merantau was undertaken by men, but currently women may also accompany their husbands to the rantau. See Naim (1974) and Kato (1982) for recent studies on the Minangkabau institution of merantau.

5 Balai Cacang is a hamlet within the village Nagari Koto nan Gadang.

6 In the days before slavery was abolished, a newly married slave girl did not have the privilege of using the annex. Instead she was given a room constructed in the kitchen area where she could receive her husband.

7 This is only one ceremony of a wedding. A Minangkabau wedding comprises a series of ceremonies over a period of two weeks. See $\mathrm{Ng}$ (1987) for a detailed description of the Minangkabau wedding.

8 A spicy stew of goat meat cooked in coconut milk. Jack-fruit and potatoes may be added for bulk.

9 Similar to 'bubble and squeak' but spiced with onions and chillies.

10 This is another typical Austronesian pattern in rituals, where men cook the main meat dish, while women cook rice and vegetables. 


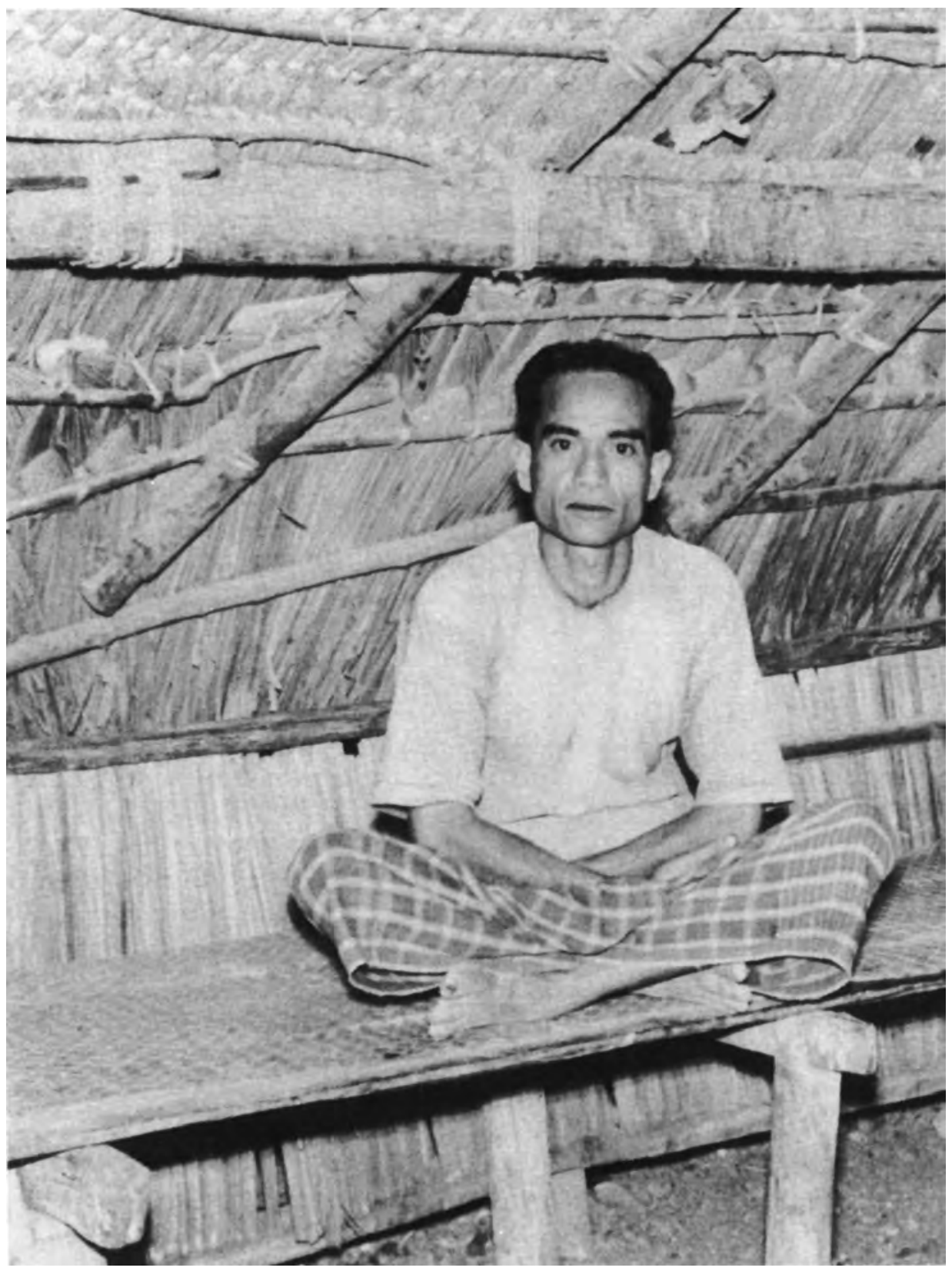

A Rotinese head of household on his sitting platform 